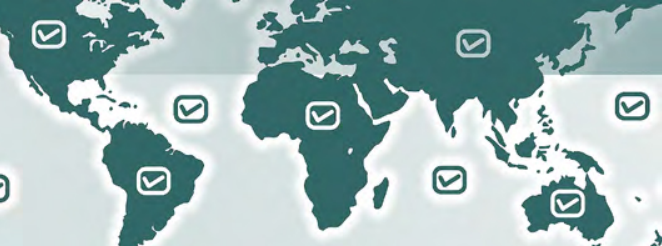

NOTES ON GEOGRAPHIC DISTRIBUTION

\title{
Resaca supports range expansion of invasive apple snails (Pomacea maculata Perry, 1810; Caenogastropoda: Ampullariidae) to the Rio Grande Valley, Texas
}

\author{
Kathryn E. Perez ${ }^{1,4}$ Victoria Garcia Gamboa, ${ }^{1}$ Caitlin M. Schneider,${ }^{2} \&$ Romi L. Burks ${ }^{2,3}$ \\ ${ }^{1}$ University of Texas Rio Grande Valley, Department of Biology, 1201 West University Drive, Edinburg, TX, USA 78501 \\ ${ }^{2}$ Southwestern University, Environmental Studies Program, 1001 East University Avenue, Georgetown, TX, USA 78626 \\ ${ }^{3}$ Southwestern University, Department of Biology, 1001 East University Avenue, Georgetown, TX, USA 78626 \\ ${ }^{4}$ Corresponding author. E-mail: perezke@gmail.com
}

\begin{abstract}
Resacas, or oxbow lakes, form from old river channels. In the Rio Grande, resacas provide habitat for diverse wildlife, including native and non-native species. Biologists unexpectedly found pink egg masses on emergent vegetation (November 2015) and later adult apple snails (May 2016) within a resaca at a former fish hatchery in Brownsville, Texas. This report extends the non-native range of Pomacea maculata Perry, 1810 by $429 \mathrm{~km}$ southeast in Texas. Our findings imply that abandoned waterbodies, such as fish hatcheries, can act as unrecognized conduits for non-native invasive species.
\end{abstract}

Key words. New record; gastropod; non-native; irrigation network; GIS

The genus Pomacea Perry, 1810 (Ampullariidae) includes the largest and most diverse group of freshwater snails native to tropical and subtropical habitats in Central and South America (HAYEs et al. 2015). In particular, 2 Pomacea species succeed globally as non-native invasive species (NNIS) (HAYES et al. 2008, HaYes et al. 2012). For example, Pomacea maculata Perry, 1810, a large freshwater apple snail native to South America from the Amazon south to the Rio de la Plata (HAYES et al. 2012), established NNIS populations in the United States in the early 1990s and has since spread to 8 southern states (BYERS et al. 2013, Burks et al. 2016). Non-native apple snails consume aquatic macrophytes (BURLAKOvA et al. 2009), compete with native species (CONNER et al. 2008, PosCH et al. 2013), disrupt ecosystem services (GiLIOLI et al. 2017), cause economic damages (Joshi \& SEBASTIAN 2006), and can harbour parasites that threaten wildlife (DodD et al. 2016) and human health (TEEM et al. 2013).

The greater Houston, Texas, metropolitan area (e.g., Harris, Brazoria, Fort Bend and Galveston counties; Fig. 1) has supported populations of $P$. maculata since 2000 (UNITED States Geological Survey 2016) in interconnected bayous, ditches and canals (BurKs et al. 2010, Burlakova et al. 2010). New records appear annually in the database (United States
Geological Survey 2016) as the highly fecund snails quickly reproduce (BARNES et al. 2008) and spread to novel habitats. However, prior to our study, no records of established apple snail populations existed from the Rio Grande Valley (RGV), the southernmost area of Texas, which lies along the northern bank of the Rio Grande River.

The RGV offers a hospitable subtropical climate for $P$. maculata and could present greater potential for reproduction and spread of this species. Resacas, otherwise known as oxbow lakes or ponds, are remnants of the Rio Grande river channel previously cut off by eroding river banks or created by sediment accumulation (AllHands 1960, Mora et al. 2001). Some resacas qualify as permanent wetlands because they receive water intermittently from pumping stations. Other resacas may be subdivided and used as fish farms or fish hatcheries (RoBINSON 2010). Although these ecosystems often get overlooked by routine monitoring efforts or become abandoned once a hatchery closes, these modified resacas can still provide valuable habitat for wetland plants, aquatic invertebrates, amphibians, fish and migratory birds within the semi-arid environment of South Texas (JAHRSDOERFER \& LESLIE 1988). For example, in Cameron County within the RGV (Fig. 1), a recent survey found that 17 permanent resacas served as habitat for an endemic threatened siren, a type of salamander with small forelimbs (LAForTune 2015). Because they support an endangered species, legal protection prevents certain resacas from being drained. However, provision of permanent water in a semi-arid region may have the unintended consequence of also supporting NNIS, including mollusk species such as Melanoides tuberculata (O. F. Müller, 1774), which are known vectors of parasites that cause human infections (BENSON \& NeILSON 2017) and already occur in the RGV.

Besides serving as habitat for wildlife, resacas provide additional ecosystem services as the RGV supports intensive agriculture production that relies on an intricate irrigation canal network for flood-irrigation of crops such as citrus (ENCIso et al. 2008). To feed this network, water from the Rio Grande 


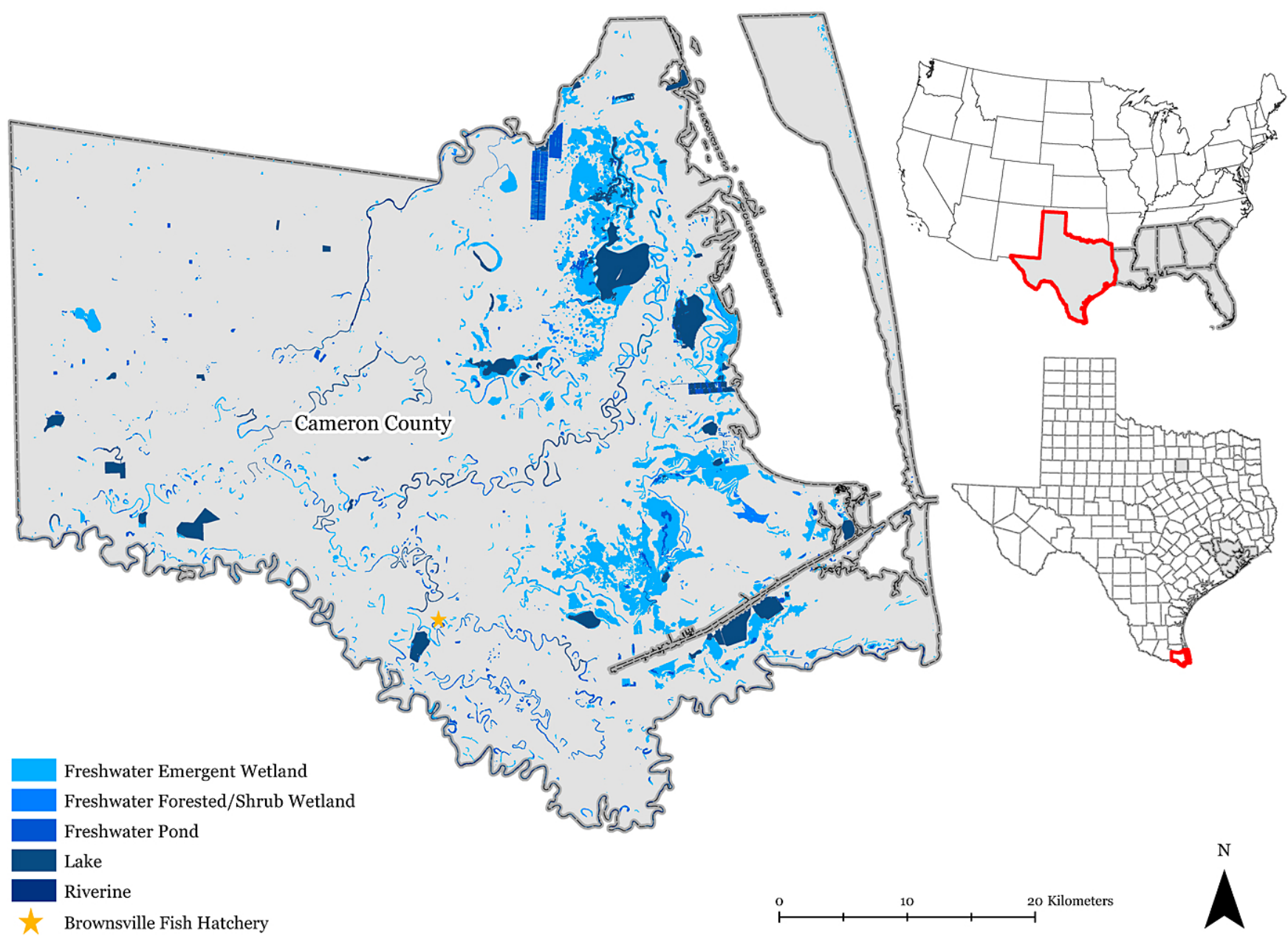

Figure 1. ArcGIS Map of the different types of wetlands and their interconnectivity within Cameron County. A red outline indicates the location of Cameron County on the inset map of Texas. A star marks the location of the Brownsville Fish Hatchery that contains the resaca that supports a reproducing population of Pomacea maculata. Inset maps of the U.S. and Texas indicate the previous range of $P$. maculata with gray shading. Data retrieved from USGS (2016).

River gets diverted through a network of over 3,200 km of canals and pipelines (KNIGHT 2009), some with permanent water and others that flood periodically. This hydrological network presents conditions potentially favorable to the spread of apple snails by providing more places to deposit egg clutches (BURKs et al. 2010, KYLE et al. 2011). In addition, the habitat linkages also allow snails refuge as they can move into deeper water (i.e., resacas or main irrigation canals) to avoid seasonal dry (DARBY et al. 2002) or cold conditions (NAYLOR 1996). Consequently, snails may survive unfavorable conditions and then increase their activity.

In parts of Texas, crop rotation of rice fields most likely minimizes detrimental effects of apple snails compared to those documented in Southeast Asia (BurLAKova et al. 2010). In Southeast Asia, herbivory by the more frequently studied Pomacea canaliculata (Lamarck, 1822), and likely P. maculata as well, annually results in billions of dollars in damage to rice (Joshi \& Sebastian 2006), and causes considerable ecological damage to natural and constructed wetlands (HoRGAN et al. 2014). However, the absence of a clear economic impact in Texas thus far does not imply a lack of vulnerable agricultural areas, especially those with permanent water. Although most studies focus on impacts to rice farming, apple snails may also damage maize, sugarcane, and citrus (NAYLOR 1996), staples of RGV agriculture (ENCISO et al. 2008). Unfortunately, as $P$. canaliculata and $P$. maculata establish new populations in non-native habitats across the globe, taxonomic confusion has plagued apple snail identifications due to morphological similarities between the two Pomacea species and recent synonymy of $P$. insularum d'Orbigny, 1835 to $P$. maculata (HAYEs et al. 2012). In this paper, we quantify initial reproductive output of a newly established population of apple snails in the RGV and genetically confirm the species identity to avoid any ambiguity.

In November 2015, researchers collected 7 snail egg clutches attached to vegetation adjacent to the resaca by clipping the stems of vegetation to prevent damaging the egg clutches (Texas Parks and Wildlife Department permit no. SPR-1014201). The resaca occurs as part of the Lower Laguna Madre Coastal Fisheries Field Office of Texas Parks and Wildlife, formerly known as the Brownsville or Olmito Fish Hatchery, and hereafter referred to as the Brownsville Fish Hatchery (Fig. 1; $\left.25.9856^{\circ} \mathrm{N},-97.5311^{\circ} \mathrm{W}\right)$. Clutches occurred on concrete fixtures, emergent vegetation such as cattails, horsetails, and grasses, and plants overhanging the pond such as the Mexican Fan Palm and other trees (Fig. 2). Researchers returned to the site in May of 2016 and collected additional clutches and found 

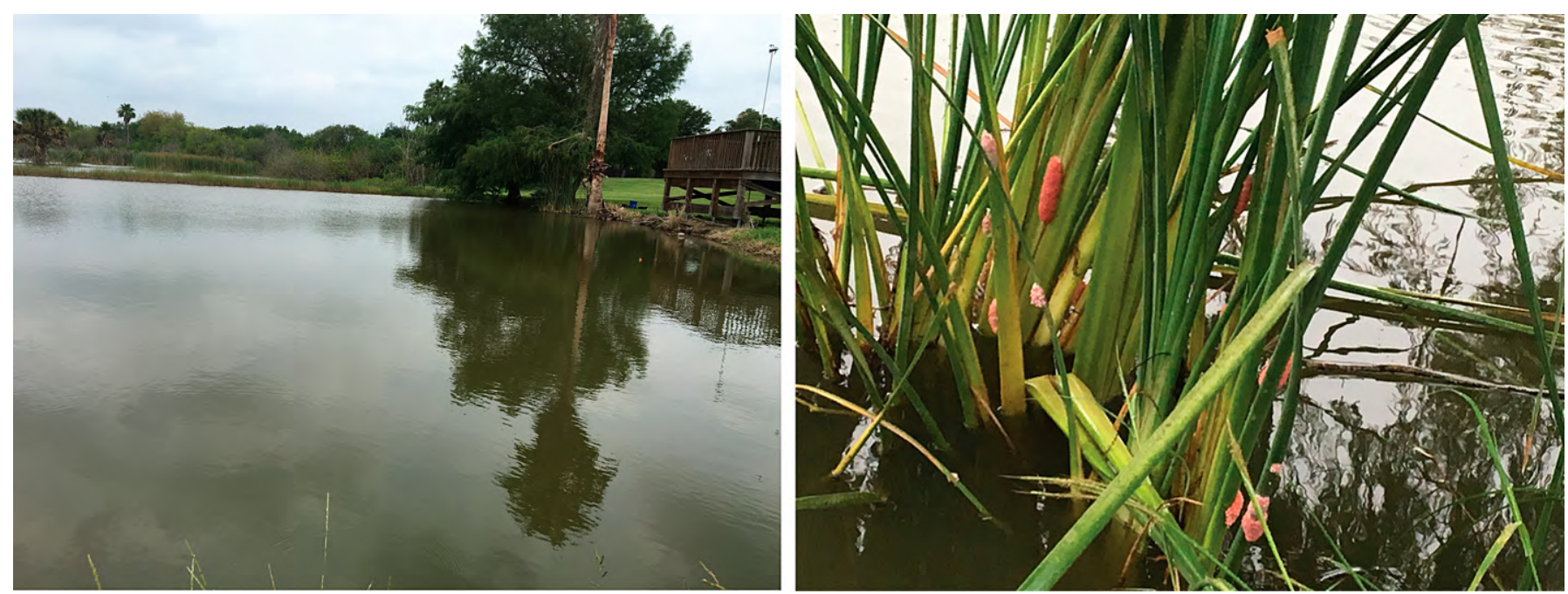

Figure 2. Images of collection site Brownsville Fish Hatchery, Brownsville, Cameron County, Texas, 20 November, 2015, collection and photo by R. Lopez and V. Garcia Gamboa. L: Overview of pond collected looking NW from bank of pond. R: Pink egg clutches on Typha sp.

the dry shells of approximately 20 adult snails (Fig. 3). Four of the adult shells (dry), hatchlings from all clutches examined (70\% ethanol), and an unhatched egg mass (dry) were deposited at the National Museum of Natural History, Smithsonian Institution (USNM 1411272-1411287).

To examine the hydrologic landscape in which this discovery of a new apple snail population occurred, we used ArcMap (v. 10.4) to create a map of wetland polygons at a county scale (Fig. 1; Cameron County) and determined distance from the nearest population recorded in the United States Geological Survey's Nonindigenous Aquatic Species Database. Geographic Information Systems (GIS) shapefiles came from the United States Fish and Wildlife Service (USFWS) National Wetlands Inventory (U.S. FISH AND WILDLIFE SERVICE 2016).

To identity species genetically, we crushed whole hatchlings

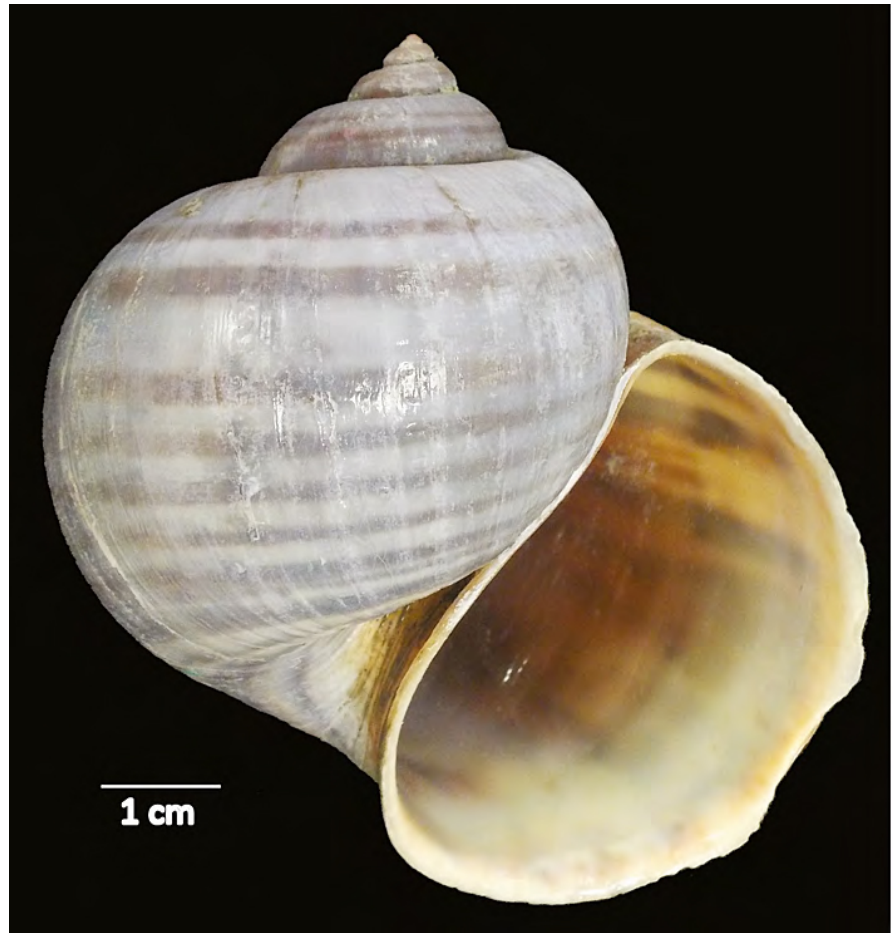

preserved in $95 \%$ ethanol and extracted DNA using $600 \mu 1$ of Cetrimonium bromide (CTAB) extraction buffer and $30 \mu \mathrm{l}$ of Proteinase $\mathrm{K}$, incubated overnight at $37^{\circ} \mathrm{C}$, and then followed with phenol-chloroform extraction (SAGHAI-MAROoF et al. 1984). Extracted DNA was resuspended in Tris-Ethylenediaminetetraacetic acid (TE) with RNAase and then additionally purified using the IBI Scientific PCR Clean Up Kit (IBI Scientific). We amplified the mitochondrial cytochrome oxidase I (COI) gene using universal primers (FolmER et al. 1994) in 25 $\mu 1$ reactions containing template DNA $(2 \mu \mathrm{L} /$ reaction $)$, reaction buffer $(1 \mathrm{M})$, Taq polymerase $(0.05 \mathrm{U} / \mu \mathrm{l})$, and dNTPs $(0.2 \mathrm{mM})$. Cycling parameters consisted of 1 cycle of $2 \mathrm{~min}$ at $92{ }^{\circ} \mathrm{C}$, then 5 cycles of $40 \mathrm{sec}$ at $92^{\circ} \mathrm{C}, 40 \mathrm{sec}$ at $40^{\circ} \mathrm{C}, 90 \mathrm{sec}$ at $72{ }^{\circ} \mathrm{C}$; then 30 cycles of $40 \mathrm{sec}$ at $92{ }^{\circ} \mathrm{C}, 40 \mathrm{sec}$ of $50{ }^{\circ} \mathrm{C}, 90$ sec at $72{ }^{\circ} \mathrm{C}$, then a final extension of $72{ }^{\circ} \mathrm{C}$ for $5 \mathrm{~min}$ with final

Figure 3. Dry adult Pomacea maculata shell collected from the Brownsville Fish Hatchery in Cameron County, Texas. 
incubation of $12{ }^{\circ} \mathrm{C}$ until termination of reaction. We purified successful amplicons using an IBI Scientific PCR Clean Up Kit and sent them for Sanger sequencing on an ABI3100 by Genewiz (South Plainfield, NJ).

Sequences for comparison were drawn from recent published literature (RAWLINGS et al. 2007; HAYES et al. 2009) accessible from Genbank (http://www.ncbi.nlm.nih.gov/genbank/). We included representative haplotypes for COI of the "Pomacea clade" (HAYEs et al. 2009), a clade of close relatives including $P$. canaliculata, P. maculata, another species of Pomacea native in the United States (P. paludosa [Say, 1829]), and P. guayanensis (Lamarck, 1822), a member of the closely related "Effusa clade" (HAYES et al. 2009), as an outgroup for phylogenetic analysis. MUSCLE (EDGar 2004) implemented at Phylogeny.fr (DEREEPER et al. 2008) was used to align sequences. Identical haplotypes were collapsed manually to retain a single individual consensus sequence. jModeltest (GUINDON \& GASCUEL 2003, DARRIBA et al. 2012) using AIC was used for selection of an appropriate model of evolution for phylogenetic analysis. We conducted phylogenetic inference and 1000 rapid bootstrap replicates (FELSENSTEIN 1985) using the maximum likelihood algorithm carried out in RaxML v. 8.2.8 (STAMATAKIS 2006). This analysis was conducted using the Cyberinfrastructure for Phylogenetic Research Gateway (MiLler et al. 2010).

To evaluate the immediate reproductive potential of the snails, we took egg clutches collected in both November 2015 (USNM 1411284-1411287) and May 2016 to the laboratory at The University of Texas Rio Grande Valley. We allowed November clutches to hatch fully and counted hatchlings over a period of one week. The total number of eggs per clutch (EPC) included unhatched eggs and hatchlings. For the additional egg masses collected in May 2016 (USNM 1411272-1411283), we immersed entire egg masses in $1.0 \mathrm{M} \mathrm{NaOH}$ overnight to allow the entire mass to separate (BARNES et al. 2008) and included all eggs in the determination of EPC. We compared EPC counts separately to allow for seasonal variation (YosHIDA et al. 2014). To compare with past literature, we measured maximum height of a hatchling's shell aperture $(n=231)$, hatchling aperture height (HAH), the same measurement referred to as "operculum width" in past literature (BARNES et al. 2008: fig. 2).

According to the National Wetlands Inventory, wetlands occupied 9.27\% of Cameron County (Fig. 1) in 2010 and included freshwater emergent wetlands, freshwater forested/ shrub wetlands, freshwater ponds, lakes, and rivers. Within that county, the Brownsville Fish Hatchery property occurs $429.2 \mathrm{~km}$ from the nearest recorded population of apple snails in Brazoria county (USGS 2016). The resaca in which we found apple snails supported stands of Typha sp. (Fig. 2) and occupied 7.7 ha. A previous fish hatchery divided the resaca into smaller basins that each occupied approximately 0.27 ha.

Based on data from the closest gauging station, a rise in water of $1.5 \mathrm{~m}$ would inundate the surrounding landscape. Apple snails occurred approximately $3.26 \mathrm{~km}$ away from the nearest large (250.85 ha) reservoir, Resaca de la Palma (Fig. 1 ; visible as the large open body of water southeast of the fish hatchery) and $10.73 \mathrm{~km}$ away from the closest branch of the Rio Grande (Fig. 1; river forms southern boundary of map). The bleached nature of adult shells collected from the resaca within the RGV (Figure 3) made identification of certain morphological characteristics suggestive of $P$. maculata (i.e., inside of pallial lip reddish-orange) versus $P$. canaliculata (i.e., inside of pallial lip unpigmented) (HAYES et al. 2012) difficult and examination of opercula characteristics impossible.

More so than the morphological characteristics, the highest likelihood tree ( -3240.676515 ; Fig. 4) from our phylogenetic analysis clearly confirmed all specimens from the RGV as $P$. maculata. Sequencing and alignment resulted in 24 sequences for a $635 \mathrm{bp}$ aligned portion of COI. No gaps or stop-codons occurred in this alignment. The TIM $2+\mathrm{I}+\mathrm{G}$ model was selected as the most appropriate for this set of data. We found 2 different COI haplotypes, BFH1 and BFH2, that differed in 8 basepairs (out of 635). Individuals $(n=4)$ from 1 egg mass had a haplotype, BFH1 (Genbank ID KX149128; USNM 1411287), known from other U.S. introduced populations including Texas (RAWLINGS et al. 2007, MARTIN et al. 2012). The other haplotype found in the other 4 egg masses (23 individuals) sequenced, BFH2 (Genbank ID KX149127; USNM 1411285-86, 141128889 ) has been previously documented in Florida (RAWLINGS et al. 2007), Louisiana (DEATon et al. 2016), and Spain (ANDreE \& LoPEZ 2013), but not previously recorded in Texas.

Six out of 7 of the clutches collected in November 2015 partially hatched, providing 231 hatchlings and many more unhatched eggs. Collectively, the 6 clutches yielded 2,479 total eggs and hatchlings with an average of $471.3 \pm 187.554$ EPC with a range of 48-1301 EPC (Fig. 5). Twelve clutches collected in May 2016 yielded 8,851 eggs, with an average of $804.6 \pm 111.843$ EPC and a range of 302-1562 EPC. Hatchling aperture height $(n=231)$ averaged $1.379 \pm 0.014 \mathrm{~mm}$.

In this study, we report a small population of $P$. maculata in a new drainage basin, the Rio Grande and a new geographic region, the $\mathrm{RGV}, 429 \mathrm{~km}$ from the nearest invasive populations in Fort Bend, Brazoria County, Texas (Fig. 1). Species identification of apple snails has historically suffered from taxonomic confusion and been difficult because of morphological similarities (HAYES et al. 2012). To avoid perpetuating the confusion that has existed, our study provides evidence from both morphological and genetic analysis that undoubtedly confirms the presence of this NNIS in the RGV.

The size of egg masses collected in November led us first to question whether these clutches could have been laid by $P$. canaliculata. These egg masses contained about 500 eggs per clutch (EPC; Fig. 5), closer to the characteristic average production of $P$. canaliculata (dashed line, values from TAMBURI \& MARTín 2011) than P. maculata egg masses (dotted line, values from BARNES et al. 2008). However, May clutches $(n=12)$, nearly twice as large (ca. 800 EPC) as the November samples, provided better support for an identification of $P$. maculata. BARnes et al. (2008) studied reproductive effort in female $P$. maculata in the Houston area of Texas by sampling in September, April, and June and found the lowest reproductive effort (lower number of EPC) at the beginning of the reproductive season (April, $767.7 \pm 74.6$ ). Reproductive effort then tripled by June $(2247.8 \pm 184.8)$ and then declined in September $(1982.0 \pm 204.2)$. Given the higher average temperatures in Brownsville compared to Houston, reproductive effort seems likely to continue its decline through November, resulting in 


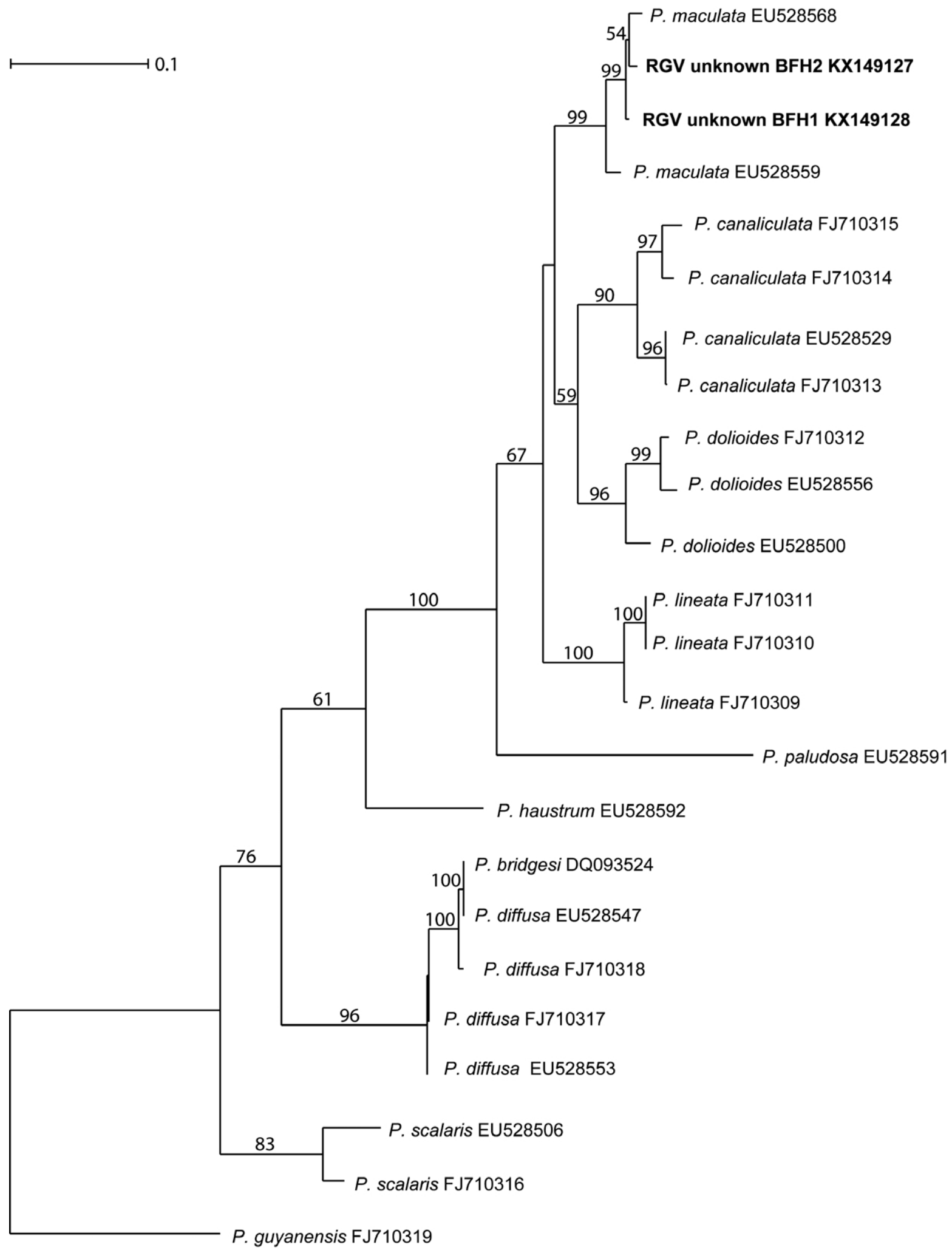

Figure 4. Maximum likelihood phylogram showing position of the Rio Grande Valley Pomacea haplotypes ( 2 haplotypes, 27 individuals sampled) in context of the Pomacea clade (HAYES et al. 2009). Numbers above branches are bootstrap values generated by 1000 rapid ML bootstraps in RaxML. Haplotypes from the Brownsville Fish Hatchery (BFH 1 and 2) are highlighted by bold text.

our low, almost $P$. canaliculata-level egg clutch counts (ca. 200 EPC; TAMBURI \& MARTín 2011).

Other factors may explain the smaller than expected egg mass sizes in November. Beyond seasonal variation, the establishment of this RGV population appears very recent and clutch mass varies widely with female size (KYLE et al.
2011). Limited food availability or density may also explain the range of clutch sizes found at our RGV site. For example, TAMBURI \& MARTín (2011) found egg mass size in P. canaliculata decreased as food availability decreased and TANAKA et al. (1999) found that increased density also decreased egg mass size. Pomacea maculata likely exhibit similar responses, and 


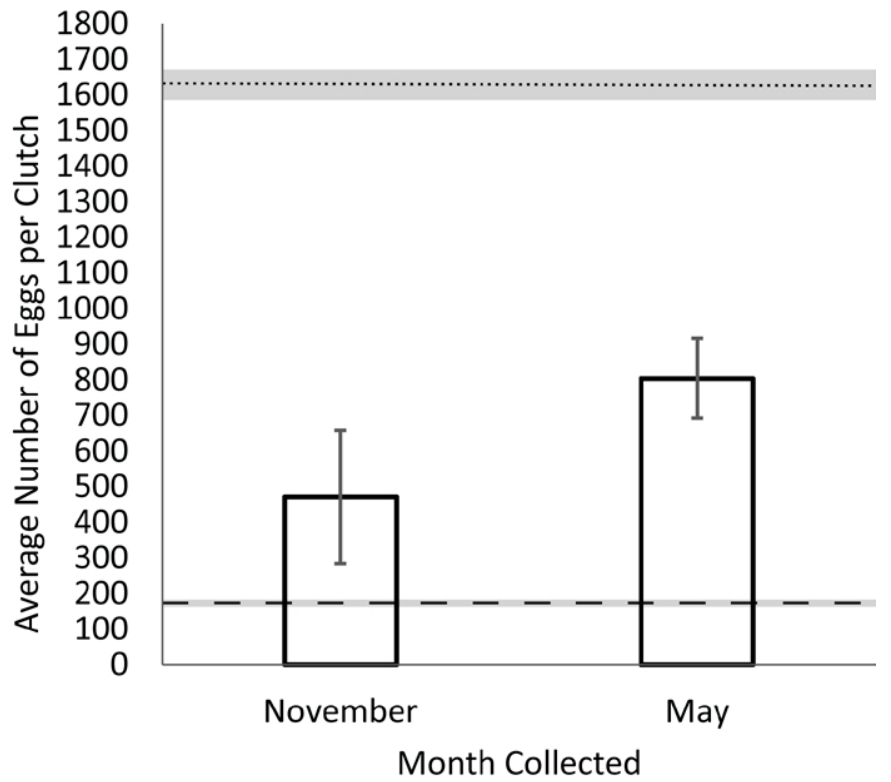

Figure 5. Average number of eggs per clutch (EPC) counted from collections in November $(n=6,471 \pm 187.6)$ and May $(n=12,804.6 \pm 111.8)$. Egg masses present in May had nearly twice as many EPC. Dotted line $(n=67$, $1626.3 \pm 121.7)$ shows the average EPC and gray bar shows the SEM for $P$. maculata (Barnes et al. 2008). Dashed line ( $n=318,186.87 \pm 0.34)$ shows the average EPC and gray bar shows the SEM for $P$. canaliculata (TAMBURI \& MARTín 2011).

future investigations will hopefully distinguish between these possibilities that our initial data could not. While often useful for distinguishing $P$. maculata from $P$. canaliculata (HAYES et al. 2012), we caution about application of egg clutch size in the field as the potential for variability and confusion exists when small $P$. maculata clutches approximate the expected egg clutch count of $P$. canaliculata.

As an alternative to egg clutch counts, hatchling aperture height (HAH) provides one of the most accurate comparisons between $P$. canaliculata and P. maculata (HAYEs et al. 2012). RGV individuals exhibited an average HAH value of $1.379 \pm$ $0.014 \mathrm{~mm}$. Published data for P. maculata from the Houston, Texas area found a HAH of $1.14 \pm 0.003 \mathrm{~mm}$ (BARNES et al. 2008). Measurement of a figure (HAYES et al. 2012: fig. 14) comparing 1-day old hatchlings of both species found $\mathrm{HAH}$ in individuals of $P$. maculata to be approximately $1 \mathrm{~mm}$ and 2.4 mm for $P$. canaliculata (HAYES et al. 2012). HAH (and overall size) of the RGV population's hatchlings appeared a bit larger than expected for newly hatched $P$. maculata, but still at least 1 whole mm smaller than P. canaliculata, thus allowing this measurement to help distinguish between the 2 species and support an identification as $P$. maculata. We hypothesize that the slight HAH differences occurred due to the rapid growth that occurs after hatching as comparable measurements occurred on Day 0 hatchlings, but the number of hours may have varied.

While morphological measures indicated an identification of $P$. maculata, we wanted the unambiguous confirmation of this new population that comes with genetic analysis. COI sequences from the RGV population formed a well-supported (99\% bootstrap support) clade with other $P$. maculata, distinct from $P$. canaliculata (Fig. 4). RAwLINGS et al. (2007) reported that the U.S. apple snail invasion initially into Florida came from sources in Brazil and Argentina. However, sampled Texas populations of $P$. maculata appeared to have invaded only from Argentina (RAwLINGs et al. 2007). Overall, low haplotype diversity in introduced populations of Pomacea occurs compared to native populations (HAYES et al. 2012), with most introduced populations retaining a single COI haplotype. The 2 distinct haplotypes present in Brownsville, separated by not just 1 , but 8 basepairs, makes this population unexpectedly diverse. Haplotype 1 also matches populations in Argentina, Florida, Georgia, Alabama, and Texas (RAwLINGs et al. 2007, MARTIN et al. 2012). This location is the first and only place that Haplotype 2 has been documented from Texas, providing a small, yet important bit of evidence that supports a Florida or Louisiana origin of the RGV population, versus spread from other Texas populations.

Pomacea maculata has been established in the Houston, Texas area since 1989 (RAwLINGS et al. 2007), however, its movement into the RGV presents a climate potentially more favorable for the survival and population growth of this tropi$\mathrm{cal} /$ subtropical species (BYERs et al. 2013). A study of macroinvertebrate diversity (McINTOSH 2014) in similar water bodies, including 3 resacas near $(<25 \mathrm{~km})$ the Brownsville Fish Hatchery, found that water temperature ranged from $12.3{ }^{\circ} \mathrm{C}$ in winter to $34.9{ }^{\circ} \mathrm{C}$ in summer, with an average annual temperature of $25.4{ }^{\circ} \mathrm{C}$ that would provide sufficient water temperatures for year-round activity in P. maculata. Thus, it seems likely that this favorable climate and places of refugia could enhance the success and spread of $P$. maculata in the RGV. The presence of egg clutches in both November and May as well as adults in May suggested that the population survived winter and continued to reproduce. The question of hatchling survival still remains open. Small hatchlings would be more vulnerable to predation by crayfish (DORN \& HAFSADI 2016), but the overall number of offspring potentially produced probably provides sufficient numbers to survive enhanced predation. Furthermore, the highly visible and seemingly vulnerable egg clutches are chemically defended and unpalatable to predators (GIGLIO et al. 2016). Coupled with the climate and habitat in South Texas, all these factors (e.g., ability to overwinter, hundreds of propagules and egg defense) indicate the likely persistence and spread of this species.

The persistent presence of this apple snail population in a decommissioned fish hatchery further highlights a potential reservoir for this invasive species to gain a foothold in a new geographic region. The resaca sits in a flat landscape connected hydrologically to a drainage network spanning the RGV, an area with extensive wetlands (Fig. 1). This interconnected drainage network has the potential to facilitate spread of this species throughout this geographic region. The occurrence in a resaca also poses challenges to easy eradication as the habitat supports $P$. maculata, a NNIS, along with another threatened species that warrants conservation, the Texas siren (Siren intermedia texana Goin, 1957) (Dixon 2013, Kline \& CARreon 2013). Pomacea maculata may also threaten other wildlife by transferring toxins linked to Avian Vacuolar Myelinopathy (DoDD et al. 2016) or by transmitting Angiostrongylus cantonensis (Chen, 1935) (TeEM et al. 2013).

The RGV encompasses a single geographical region, 
however, many areas outside Texas exist with similar hydrologic landscapes covered with oxbow lakes and abandoned fish ponds. Routine monitoring of these types of ecosystems might be valuable for avoiding the potential ecosystem damage of NNIS. MARTIN et al. (2012) described the history of an apple snail introduction in Mobile, Alabama, to a similarly sized wetland. Over a 10-year period, state and local governments have attempted to control the apple snail population using chemical and biological controls, ecosystem modifications, and physical removal, yet the invasive population remains. In Florida, management effort by hand-picking has been found to be effective and cost-effective (BERNATIS \& WARREN 2014) for apple snail control at the initial stages of a population that remains relatively localized. Economically, apple snails could have an impact in the RGV as current efforts seek to restore the resacas' ecosystem functions including connectivity (Resaca Restoration Project, Brownsville Public Utilities Board). The case of $P$. maculata in South Texas clearly demonstrates that abandoned waterbodies within hospitable climates may act as conduits for invasive species and thus warrant monitoring and early intervention.

\section{ACKNOWLEDGEMENTS}

We thank the University of Texas Rio Grande Valley's (UTRGV) Science Education Grant \#52007568 funded by the Howard Hughes Medical Institute, ADVANCE Institutional Transformation Grant (NSF\# 1209210), and UTRGV College of Sciences for financial support. We thank John Brush and Tim Brush for alerting us to the presence of egg masses and the staff at Brownsville Fish Hatchery for access to the ponds and Jude Benavides for water temperature data. Ruth Lopez and Eli Ruiz assisted with field collections. Anwar Sounny-Slitine provided GIS advice to co-author CMS. We also thank Sofia R. Campos, Carson E. Savrick and the Keck Molecular Biology Program at Southwestern University for initial sequence data and Dr. Pablo Martín for data on the average EPC for $P$. canaliculata. Carson E. Savrick, Bianca Perez, Rodrigo B. Salvador, and an anonymous reviewer provided valuable comments on an earlier version of the manuscript.

\section{LITERATURE CITED}

Allhands, J.L. 1960. Railroads to the Rio. Salado, Texas: Anson Jones Press. 213 pp.

AndReE, K.B. \& M.A. López. 2013. Species identification from archived snail shells via genetic analysis: a method for DNA extraction from empty shells. Molluscan Research 33: 1-5. https://doi.org/ 10.1080/13235818.2012.754141

Barnes, M.A., R.K. Fordham, J.J. Hand \& R.L. Burks. 2008. Fecundity of the exotic applesnail, Pomacea insularum. Journal of the North American Benthological Society 27: 738-745. https:// doi.org/https://doi.org/10.1899/08-013.1

Benson, A.J. \& M.E. Neilson. 2017. Melanoides tuberculata. USGS Nonindigenous Aquatic Species Database, Gainesville, FL. Accessed at: https://nas.er.usgs.gov/queries/factsheet.aspx? SpeciesID=1037, 14 April 2017.

Bernatis, J.L. \& G.L. WARren. 2014. Effectiveness of a hand removal program for management of nonindigenous spple snails in an urban pond. Southeastern Naturalist 13: 607-618. https://doi. org/10.1656/058.013.0320

BuRKs, R.L., C.H. Kyle \& M.K. Trawick. 2010. Pink eggs and snails: field oviposition patterns of an invasive snail, Pomacea insularum, indicate a preference for an invasive macrophyte. Hydrobiologia 646: 243-251. https://doi.org/10.1007/s10750-010-0167-1

Burks, R.L., A.E. Miller \& A.L. Hill. 2016. Pomacea maculata. CABI invasive species compendium. Accessed at http://www.cabi. org/isc/datasheet/116486, 20 November 2016.

Burlakova, L.E., A.Y. Karatayev, D.K. Padilla, L.D. Cartwright $\&$ D.N. Hollas. 2009. Wetland restoration and invasive species: apple snail (Pomacea insularum) feeding on native and invasive aquatic plants. Restoration Ecology 17: 433-440. https://doi. org/10.1111/j.1526-100X.2008.00429.X

Burlakova, L.E., D.K. Padilla, A.Y. KarataYev, D.N. Hollas, L.D. CARTwright \& K.D. Nichol. 2010. Differences in population dynamics and potential impacts of a freshwater invader driven by temporal habitat stability. Biological Invasions 12: 927-941. https://doi.org/10.1007/s10530-009-9513-5

Byers, J.E., W.G. McDowell, S.R. Dodd, R.S. Haynie, L.M. Pintor \& S.B. WILDE. 2013. Climate and $\mathrm{pH}$ predict the potential range of the invasive apple snail (Pomacea insularum) in the southeastern United States. PLoS ONE 8: e56812. https://doi.org/10.1371/journal.pone. 0056812

Chen, H.T. 1935. Un nouveau nématode pulmonaire, Pulmonema cantonensis n.g., n.sp., des rats de Canton. Annales de Parasitologie Humaine et Comparée 13: 312-317.

Conner, S.L., C.M. Pomory \& P.C. Darby. 2008. Density effects of native and exotic snails on growth in juvenile apple snails Pomacea paludosa (Gastropoda: Ampullariidae): a laboratory experiment. Journal of Molluscan Studies 74: 355-362. https://doi.org/10.1093/ mollus/eyn 024

D’Orbigny, A.D. 1835. Voyage dans l'Amérique Méridionale: (le Brésil, la république orientale de l'Uruguay, la République argentine, la Patagonie, la république du Chili, la république de Bolivia, la républiquedu Pérou), exécuté pendant les années 1826, 1827, 1828, $1829,1830,1831,1832$, et 1833. Paris: Chez Pitois-Levrault et c.e. $672 \mathrm{pp}$.

Darby, P.C., R.E. Bennetts, S.J. Miller \& H.F. Percival. 2002. Movements of Florida apple snails in relation to water levels and drying events. Wetlands 22: 489-498. http://dx.doi.org/10.1672/ 0277-5212(2002)022[0489:mofasi]2.0.co;2

Darriba, D., G. Taboada, R. Doallo \& D. Posada. 2012. jModelTest 2: more models, new heuristics and parallel computing. Nature Methods 9: 772. https://doi.org/10.1038/nmeth.2109

Deaton, L.E., W. Schmidt, B. Leblanc, J. Carter, K. Mueck \& S. Merino. 2016. Physiology of the invasive apple snail Pomacea maculata: tolerance to low temperatures. Journal of Shellfish Research 35: 207-210. https://doi.org/10.2983/035.025.0122

Dereeper, A., V. Guignon, G. Blanc, S. Audic, S. Buffet, F. Chevenet, J.F. Dufayard, S. Guindon, V. Lefort, M. Lescot, J.M. Claverie \& O. Gascuel. 2008. Phylogeny.fr: robust phylogenetic analysis for the non-specialist. Nucleic Acids Research 36 (Suppl. 2): W465-W469. https://doi.org/10.1093/nar/gkn180

Dixon, J.R. 2013. Amphibians and reptiles of Texas. College Station, Texas: Texas A\&M University Press. 432 pp.

Dodd, S.R., R.S. Haynie, S.M. Williams \& S.B. Wilde. 2016. Alternate food-chain transfer of the toxin linked to Avian Vacuolar Myelinopathy and implications for the endangered Florida snail kite (Rostrhamus sociabilis). Journal of Wildlife Diseases 52: 335-344. https://doi.org/10.7589/2015-03-061

DoRn, N.J. \& M. HAFSADI. 2016. Native crayfish consume more nonnative than native apple snails. Biological Invasions 18: 159-167. https://doi.org/10.1007/s10530-015-0998-9

EDGAR, R.C. 2004. MUSCLE: multiple sequence alignment with high accuracy and high throughput. Nucleic Acids Research 32: 1792-1797. https://doi.org/10.1093/nar/gkh340 
Enciso, J., J.W. Sauls, R.P. Wiedenfeld \& S.D. Nelson. 2008. Impacts of irrigation on citrus in the Lower Rio Grande Valley. T.A.M.A. Extension: Texas A\&M Agrilife Extension. B-6205: 16.

Felsenstein, J. 1985. Confidence limits on phylogenies - an approach using the bootstrap. Evolution 39: 783-791. https://doi.org/10.2307/ 2408678

Folmer, O., M. Black, W. Hoeh, R. Lutz \& R. Vrijenhoek. 1994. DNA primers for amplification of mitochondrial cytochrome $c$ oxidase subunit I from diverse metazoan invertebrates. Molecular Marine Biology and Biotechnology 3: 294-299.

Giglio, M.L., S. Ituarte, M.Y. Pasquevitch \& H. Heras. 2016. The eggs of the apple snail Pomacea maculata are defended by indigestible polysaccharides and toxic proteins. Canadian Journal of Fisheries and Aquatic Sciences 94: 777-785. https://doi. org/10.1139/cjz-2016-0049

Gilioli, G., G. Schrader, N. Carlsson, E. van Donk, C.H.A. van Leeuwen, P.R. Martín, S. Pasquali, M. Vilà \& S. Vos. 2017. Environmental risk assessment for invasive alien species: A case study of apple snails affecting ecosystem services in Europe. Environmental Impact Assessment Review 65: 1-11. https://doi. org/10.1016/j.eiar.2017.03.008

Goin, C. J. 1957. Description of a new salamander of the genus Siren from the Rio Grande. Herpetologica 13: 37-42. http://www.jstor. org/stable/3890151

Guindon, S. \& O. Gascuel. 2003. A simple, fast and accurate method to estimate large phylogenies by maximum-likelihood. Systematic Biology 52: 696-704. https://doi.org/10.1080/10635150390235520

Hayes, K.A., R. Cowie, S. Thiengo \& E.E. Strong. 2012. Comparing apples with apples: clarifying the identities of two highly invasive Neotropical Ampullariidae (Caenogastropoda). Zoological Journal of the Linnean Society 166: 723-753. https://doi.org/10.1111/j.10963642.2012.00867.x

Hayes, K.A., R.L. Burks, A. Castro-Vazquez, P.C. Darby, H. Heras, P.R. Martín, J. Qiu, S.C. Thiengo, I.A. Vega, T. WadA, Y. Yusa, S. Burela, M.P. Cadierno, J.A. Cueto, F.A. Dellagnola, M.S. Dreon, M.V. Frassa, M. Giraud-Billoud, M.S. Godoy, S. Ituarte, E. Koch, K. Matsukura, M.Y. Pasquevich, C. RodriGuez, L. Saveanu, M.E. Seuffert, E.E. Strong, J. Sun, N.E. TAMburi, M.J. Tiecher, R.L. TuRner, P.L. VALENTINE-Darby \& R.H. CowIE. 2015. Insights from an integrated view of the biology of apple snails (Caenogastropoda: Ampullariidae). Malacologia 58: 245-302. https://doi.org/10.4002/040.058.0209

HaYes, K.A., R.H. Cowie \& S.C. ThienGo. 2009. A global phylogeny of apple snails: Gondwanan origin, generic relationships and the influence of outgroup choice (Caenogastropoda: Ampullariidae). Biological Journal of the Linnean Society 98: 61-76. https://doi. org/10.1111/j.1095-8312.2009.01246.x

Hayes, K.A., R.C. Joshi, S.C. ThiEnGo \& R.H. Cowie. 2008. Out of South America: multiple origins of non-native apple snails in Asia. Diversity and Distributions 14: 701-712. https://doi.org/10.1111/ j.1472-4642.2008.00483.x

Horgan, F.G., A.M. Stuart \& E.P. Kudavidanage. 2014. Impact of invasive apple snails on the functioning and services of natural and managed wetlands. Acta Oecologica 54: 90-100. https://doi. org/10.1016/j.actao.2012.10.002

JAHRSDOERFER, S.E. \& D.M. LeSLIE. 1988. Tamaulipan brushland of the Lower Rio Grande Valley of South Texas: description, human impacts, and management options. US Fish Wildlife Service Biological Report 88(36). 63 pp.

Joshi, R.C. \& L.S. SEbastian. 2006. Global advances in ecology and management of Golden Apple Snails. Nueva Ecija: P.R.R. Institute. $600 \mathrm{pp}$.

Kline, R.J. \& L. B. Carreon. 2013. Population genetics of the threatened South Texas Siren (large form SP1). Final report to Texas Parks and Wildlife. 12 pp.

KNIGHT, L. 2009. A field guide to irrigation in the lower Rio Grande
Valley. E.A.D. Texas Department of Transportation, Historical Studies Branch. 285 pp.

Kyle, C.H., A.W. Kropf \& R.L. Burks. 2011. Prime waterfront real estate: apple snails choose wild taro for oviposition sites. Current Zoology 57: 630-641. https://doi.org/10.1093/czoolo/57.5.630

LAFortune, T.C. 2015. Species identification and habitat assessment of the South Texas siren. Brownsville: University of Texas at Brownsville. 103 pp.

LAMARCK, J.-B. P. A. de M. de. 1822. Histoire naturelle des animaux sans vertèbres, présentant les caractères généraux et particuliers de ces animaux, leur distribution, leurs classes, leurs familles, leurs genres, et la citation des principales espèces qui s'y rapportent ; précédée d'une introduction offrant la détermination des caractères essentiels de l'animal, sa distinction du végétal et des autres corps naturels ; enfin, l'exposition des principes fondamentaux de la zoologie. Paris: l'auteur. $451 \mathrm{pp}$.

Martin, C.W., K.M. Bayha \& J.F. Valentine. 2012. Establishment of the invasive island apple snail Pomacea insularum (Gastropoda: Ampullaridae) and eradication efforts in Mobile, Alabama, USA. Gulf of Mexico Science 30: 30-38.

McINTosh, L.M. 2014. Resaca ecosystem development: colonization and succession of the macroinvertebrate community. Brownsville: The University of Texas at Brownsville. 112 pp.

Miller, M.A., W. Pfeiffer \& T. Schwartz. 2010. Creating the CIPRES Science Gateway for inference of large phylogenetic trees. Proceedings of the Gateway Computing Environments Workshop (GCE), New Orleans, LA. 8 pp. https://doi.org/10.1109/ GCE.2010.5676129

Mora, M.A., D. Papoulias, I. Nava \& D.R. Buckler. 2001. A comparative assessment of contaminants in fish from four resacas of the Texas, USA-Tamaulipas, Mexico border region. Environment International 27: 15-20.

MüLLER, O.F. 1774. Vermium terrestrium et fluviatilium seu animalium infusoriorum, helminthicorum, et testaceorum, non marinorum, Succinta Historia. Paris: Hafniae et Lipsiae. 72 pp.

NAYLOR, R. 1996. Invasions in agriculture: assessing the cost of the folden apple snail in Asia. Ambio 25: 443-448. http://www.jstor. org $/$ stable $/ 4314515$

PerRY, G. 1810-1811. Arcana; or the museum of natural history: containing the most recent discovered objects. London: James Stratford. $16 \mathrm{pp}$.

Posch, H., A.L. Garr \& E. Reynolds. 2013. The presence of an exotic snail, Pomacea maculata, inhibits the growth of juvenile Florida apple snails, Pomacea paludosa. Journal of Molluscan Studies 79: 383-385. https://doi.org/10.1093/mollus/eyt034

Rawlings, T.A., K.A. Hayes, R.H. Cowie \& T.M. Collins. 2007. The identity, distribution, and impacts of non-native apple snails in the continental United States. BMC Evolutionary Biology 7: 1-14. https://doi.org/10.1186/1471-2148-7-97

Robinson, C.M.I. 2010. Resacas. Handbook of Texas online. Accessed at http://www.tshaonline.org/handbook/online/articles/ rbrnp, 12 December 2016.

Saghai-Maroof, M.A., K.M. Soliman, R.A. Jorgensen \& R.W. ALLARD. 1984. Ribosomal DNA spacer length in barley: Mendelian inheritance, chromosomal location, and population dynamics. Proceedings of the National Academy of Science USA 81: 8014-8018. https://doi.org/10.1073/pnas.81.24.8014

SAY, T. 1829. Descriptions of some new terrestrial and fluviatile shells of North America. The New Harmony Disseminator of Useful Knowledge 3: 260.

StAMATAKIS, A. 2006. RAxML-VI-HPC: maximum likelihood-based phylogenetic analyses with thousands of taxa and mixed models. Bioinformatics 22: 2688-2690. https://doi.org/10.1093/bioinformatics/btl446

TAMBURI, N.E. \& P.R. MARTín. 2011. Effects of food availability on reproductive output, offspring quality and reproductive efficiency 
in the apple snail Pomacea canaliculata. Biological Invasions 13: 2351-2360. https://doi.org/10.1007/s10530-011-0047-2

Tanaka, K., T. Watanabe, H. Higuchi, K. Miyamoto, Y. Yusa, T. Kiyonaga, H. Kiyota, Y. Suzuki \& T. Wada. 1999. Densitydependent growth and reproduction of the apple snail, Pomacea canaliculata: a density manipulation experiment in a paddy field. Researches on Population Ecology 41: 253-262. https://doi. org $/ 10.1007 / \mathrm{s} 101440050029$

Teem, J.L., Y. Qvarnstrom, H.S. Bishop, A.J. da Silva, J. Carter, J. White-McLean \& T. Smith. 2013. The occurrence of the rat lungworm, Angiostrongylus cantonensis, in nonindigenous snails in the Gulf of Mexico region of the United States. Hawai' $i$ Journal of Medicine and Public Health 72(6) Supplement 2: 11-14.

U.S. Fish AND WildLife SERvice. 2016. National Wetlands Inventory Vector. Accessed at https://www.fws.gov/wetlands/Data/StateDownloads.html, 29 September 2016.

United States Geological Survey. 2016. Nonindigenous aquatic species database. Accessed at https://nas.er.usgs.gov, 28 April 2016.
Yoshida, K., K. Matsukura, N.J. Cazzaniga \& T. Wada. 2014. Tolerance to low temperature and desiccation in two invasive apple snails, Pomacea canaliculata and $P$. maculata (Caenogastropoda: Ampullariidae), collected in their original distribution area (northern and central Argentina). Journal of Molluscan Studies 80: 62-66. https://doi.org/doi:10.1093/mollus/eyt042

Authors' contributions. VGG collected the snail data, RLB provided the preliminary genetic identification, VGG and KEP conducted laboratory work and phylogenetic analysis, CMS did the ArcGIS work, RLB and KEP wrote the text and all authors contributed edits.

Received: 31 January 2017

Accepted: 27 April 2017

Academic editor: Rodrigo B. Salvador 